Article

\title{
Preferential Use of the Perchlorate over the Nitrate in the Respiratory Processes Mediated by the Bacterium Azospira sp. OGA 24
}

\author{
Francesco Guarino $^{1}\left(\mathbb{D}\right.$, Oriana Motta ${ }^{2, *(\mathbb{D}}$, Mimmo Turano ${ }^{3} \mathbb{D}$, Antonio Proto ${ }^{1}$ \\ and Giovanni Vigliotta ${ }^{1, *}$ \\ 1 Department of Chemistry and Biology "A. Zambelli”, University of Salerno, via Giovanni Paolo II, \\ 84084 Fisciano (SA), Italy; fguarino@unisa.it (F.G.); aproto@unisa.it (A.P.) \\ 2 Department of Medicine, Dentistry and Surgery "Scuola Medica Salernitana", University of Salerno, \\ via S. Allende, 84081 Baronissi (SA), Italy \\ 3 Department of Structural and Functional Biology, University of Naples "Federico II", \\ Complesso Universitario Monte Santangelo, via Cinthia, 80126 Napoli, Italy; mimmo.turano@unina.it \\ * Correspondence: omotta@unisa.it (O.M.); gvigliotta@unisa.it (G.V.)
}

Received: 24 June 2020; Accepted: 4 August 2020; Published: 6 August 2020

\begin{abstract}
Here we report the results obtained for a strain isolated from a polluted site and classified as Azospira sp. OGA 24. The capability of OGA 24 to utilize perchlorate and nitrate and the regulation of pathways were investigated by growth kinetic studies and analysis of messenger RNA (mRNA) expression of the genes of perchlorate reductase alpha subunit $(p c r A)$, chlorite dismutase $(c l d)$, and periplasmic nitrate reductase large subunit (napA). In aerobic conditions and in a minimal medium containing $10 \mathrm{mM}$ acetate as carbon source, $5.6 \pm 0.34 \mathrm{mmol} \mathrm{L}^{-1}$ perchlorate or $9.7 \pm 0.22 \mathrm{mmol}$ $\mathrm{L}^{-1}$ nitrate were efficiently reduced during the growth with $10 \mathrm{mM}$ of either perchlorate or nitrate. In anaerobiosis, napA was completely inhibited in the presence of perchlorate as the only electron acceptor, $p c r A$ was barely detectable in nitrate-reducing conditions. The cell growth kinetics were in accordance with expression data, indicating a separation of nitrate and perchlorate respiration pathways. In the presence of both compounds, anaerobic nitrate consumption was reduced to $50 \%$ $\left(4.9 \pm 0.4\right.$ vs. $9.8 \pm 0.15 \mathrm{mmol} \mathrm{L}^{-1}$ without perchlorate), while that of perchlorate was not affected ( $7.2 \pm 0.5$ vs. $6.9 \pm 0.6 \mathrm{mmol} \mathrm{L}^{-1}$ without nitrate). Expression analysis confirmed the negative effect of perchlorate on nitrate respiration. Based on sequence analysis of the considered genes and $16 \mathrm{~S}$ ribosomal gene (rDNA), the taxonomic position of Azospira sp. OGA 24 in the perchlorate respiring bacteria (PRB) group was further defined by classifying it in the oryzae species. The respiratory characteristics of OGA 24 strain make it very attractive in terms of potential applications in the bioremediation of environments exposed to perchlorate salts.
\end{abstract}

Keywords: perchlorate respiring bacteria (PRB); strain Azospira sp. OGA 24; emerging pollutants; bioremediation; Reverse transcriptase-polymerase (RT-PCR); periplasmic and membrane nitrate reductase

\section{Introduction}

Perchlorate $\left(\mathrm{ClO}_{4}^{-}\right)$is a ubiquitous ion released into the environment by anthropogenic and natural sources. Military and commercial applications of perchlorate salts as oxidizers in propellants, flares, munitions, matches, fireworks, blasting agents are the main anthropogenic perchlorate sources, while the natural ones are the nitrate salts from Chilean deposits, phosphorus-bearing minerals founded in arid locations, potash ore from New Mexico and Canada [1]. Some studies have moreover demonstrated that relative significant quantities of perchlorate are naturally formed in the atmosphere, especially during thunderstorms [2,3]. Nowadays, perchlorate is being found as a nearly ubiquitous 
contaminant in water, beverages, fresh produce, and other sources of human exposure all over the world [4], and its toxicity raises public health concerns. The main effect on human beings is its action on the thyroid gland by inhibiting iodide uptake and synthesis of thyroid-stimulating hormone, with serious impairments of growth, metabolism, and reproduction [5-8]. Acute exposure has been shown to affect the reproductive, nervous, and immune systems [9]. It has also been related to thyroid cancer and teratogenesis during the first trimester of pregnancy [10]. Because of its toxicity, the US Environmental Protection Agency (US EPA) included perchlorate in the Drinking Water Contaminant Candidate List [11] and in 2011 announced a decision to regulate perchlorate under the Safe Drinking Water Act (US EPA, 2011).

In this scenario, the decontaminating processes of the environments exposed to perchlorate salts are becoming a growing challenge, especially in the case of water for drinking and agricultural uses.

Perchlorate is a strong oxidizing agent, but it is a non-reactive ion because of the high activation energy required for its reduction. Accordingly, its high stability makes inefficient the traditional physico-chemical treatment processes of removal and destruction and causes its diffusion and permanence in the environment [11-13]. Nevertheless, perchlorate can be biologically reduced to chloride by native soil and groundwater bacteria; its high reduction potential $\left(\mathrm{E}^{\circ}=1.287 \mathrm{~V}\right)$ makes it a favorable electron acceptor under anaerobic conditions.

Bacteria able to transform perchlorate into harmless chloride (PRB or DPRB: Perchlorate Reducing Bacteria/Dissimilatory Perchlorate Reducing Bacteria) by respiratory reduction processes are widely distributed in the environment and in the last two decades a lot of them have been isolated and characterized. Almost all isolated PRB, with few exceptions, belong to the Proteobacteria class ( $\alpha, \beta$, $\gamma$ and $\varepsilon$ ) [14], and most of them fall into the Rhodociclaceae family of beta-Proteobacteria, in the genus Azospira [15,16] and Dechloromonas [17-19]. They are Gram negative bacteria, facultative anaerobes or microaerophilic, not fermentative, and almost all of them are facultative denitrifiers [17,20-24]. In very few cases, the ability to respire perchlorate has been described among the phylum of Firmicutes and the domain of Archaea [25].

Perchlorate respiration occurs through the complete reduction of the chlorine atom according to the sequence $\mathrm{ClO}_{4}{ }^{-}, \mathrm{ClO}_{3}{ }^{-}, \mathrm{ClO}_{2}{ }^{-}, \mathrm{Cl}^{-}+\mathrm{O}_{2}$ [26]. The reduction process is mediated by a periplasmic perchlorate reductase (Pcr) that reacts with both perchlorate and chlorate releasing chlorite ion $\left(\mathrm{ClO}_{2}{ }^{-}\right)$, and a chlorite dismutase (Cld), localized in the outer membrane, that reduces chlorite to chloride and oxygen $[27,28]$. Due to the ability of Pcr to recognize both substrates, PRB can also grow anaerobically with chlorate as electron acceptors. However, in a specific group of chlorate respiring bacteria (CRB), only the reduction of chlorate occurs because the Pcr is absent and the chlorate reductase is unable to react with perchlorate $[19,29,30]$.

In situ and ex situ decontamination processes for perchlorate have primarily focused on biological technologies based on the use of PRB [27,31,32] since they do not generate toxic products and are also practical to use. The possibility of employing these microorganisms in bioremediation plans is connected to the knowledge of their physiology and of the main environmental factors that regulate the respiration of perchlorate. Currently, little is known about the latter, but a key role has been defined for oxygen, perchlorate, and nitrate. Aerobiosis inhibits the respiration pathway in all characterized strains, both at level of perchlorate reductase and chlorite dismutase enzymes [20,23,29,33,34]. The perchlorate in anoxic conditions is an inducer of the pathway; however, concentrations of $\sim 30 \mathrm{mM}$ have been described to be toxic to most PRB $[35,36]$. In addition, the induction of the "energy taxis", attraction toward the electron acceptor for energy production, and an oxygen inhibition of this physiologic response have also been reported for perchlorate [37]. Variable action was found for nitrate, and several regulatory mechanisms were hypothesized. Most of PRB are denitrifiers [17,21,24,38], and commonly an inhibitory effect has been reported for nitrate on the perchlorate pathway [21,34,37,39]. The absence of inhibition, although less frequently, was also described, with capability of simultaneous consumption of perchlorate and nitrate [33,40]. A further complication in defining the role of nitrate is that the two dissimilation processes have often been molecularly related at the level of terminal reductase, that is, 
the nitrate reductase of denitrifying bacteria and the perchlorate reductase of PBR can reduce both perchlorate and nitrate $[33,34,37,40,41]$.

While the inhibitory effect of the nitrate on the perchlorate pathway is well known, to date no effects of the perchlorate on nitrate respiration have been observed in environmental isolated PRB.

In this paper, we investigate the molecular mechanism involved in the perchlorate respiration of Azospira sp. OGA 24, a PRB previously isolated in our research group from a highly polluted site through an enrichment procedure and characterized for its interesting denitrification capability [42-44]. We present new elements regarding the regulation of perchlorate and nitrate respiration in PRB, which are potentially interesting for applications in bioremediation programs. Furthermore, through a comparative phylogenetic analysis based on sequenced genes of respiratory pathways of perchlorate and nitrate and on 16S rRNA, we clarify the taxonomic position of the strain OGA 24 in the PRB group.

\section{Materials and Methods}

\subsection{Materials and Bacterial Strains}

For the growth and characterization of Azospira sp. OGA 24, a minimal VG medium [23,26,45] was utilized, modified by the addition of a mixture of B vitamins [42]. Media were solidified with $15 \mathrm{gL}^{-1}$ bactoagar (Difco). Azospira oryzae PS (DSM $13638 \mathrm{~T}$ ) was purchased from DSMZ microorganisms collection (http://www.dsmz.de/). Escherichia coli (strain JM109) was purchased from Promega (http://www.promega.com/products; cat. No P 9751). Pseudomonas fluorescens strain was derived from the bacterial collection deposited in the laboratory of microbiology directed by G. Vigliotta. Acetate $\left(\mathrm{CH}_{3} \mathrm{COONa}\right)$, perchlorate $\left(\mathrm{NaClO}_{4}\right)$, chlorate $\left(\mathrm{NaClO}_{3}\right)$, and nitrate $\left(\mathrm{KNO}_{3}\right)$ were purchased from Aldrich (Milan, Italy). For the preparation of microbiological media, molecular tests and all solutions, we used water for Ion Chromatography Supelco with conductivity $\leq 2 \mu \mathrm{S} / \mathrm{cm}$. This water was used for all ion chromatography analysis and did not present any anion measurable in our chromatography experiment.

\subsection{Growth Conditions}

Kinetic analysis of the growth and utilization of electron acceptors were conducted in a modified VG medium in the presence of $10 \mathrm{mM}$ sodium acetate as carbon source. Briefly, pre-inoculated samples in VG medium were grown to the exponential phase in aerobic conditions with constant shaking at $200 \mathrm{rpm}$. After that, they were diluted to an $\mathrm{OD}_{600}$ (optical density at $600 \mathrm{~nm}$ ) of 0.005 [about $5 \times 10^{6}$ unity forming colonies (CFUs) $\mathrm{mL}^{-1}$ ] in fresh VG medium containing sodium acetate and incubated aerobically or anaerobically in the presence of $10 \mathrm{mM}$ each of appropriate electron acceptor (sodium perchlorate, potassium nitrate, chlorate), with constant shaking (200 rpm) at $40{ }^{\circ} \mathrm{C}$. At the indicated times, aliquots of culture were collected, both for growth monitoring by $\mathrm{OD}_{600}$ measurement and for perchlorate, nitrate, chlorate, and nitrite concentration evaluation. A linear regression analysis of the natural logarithms of the $\mathrm{OD}_{600}$ values was performed to estimate the growth rates $\left(R^{2} \geq 0.9\right)$. For the growth of the controls with only oxygen, after the dilution to $0.005 \mathrm{OD}_{600}$ in VG medium, $10 \mathrm{mM}$ sodium acetate, the samples were incubated in aerobiosis without the addition of perchlorate or nitrate.

The medium for anaerobic growth was brought to the boil, to remove $\mathrm{O}_{2}$, and then, it was dispensed in serum bottles that were capped with thick butyl rubber stoppers, crimped with an aluminum seal, and autoclaved $20 \mathrm{~min}$ at $121^{\circ} \mathrm{C}$ for sterilization. All the anaerobic manipulations were performed using an anaerobic Glove box under a $\mathrm{N}_{2} / \mathrm{CO}_{2}(80: 20, v / v)$ atmosphere.

Perchlorate tolerance was evaluated by growing bacteria on agarized VG medium supplemented with concentrations of perchlorate ranging from $5 \mathrm{mM}$ to $4.0 \mathrm{M}$, in aerobiosis or in anaerobiosis. All experiments were produced in triplicates. 


\subsection{Perchlorate and Chlorate Determination}

Perchlorates and chlorates were determined using a Liquid Chromatography-Mass Spectrometry (LC-MS).

Liquid Chromatography: a 1525 binary pump (Waters, Milford, MA, USA) was used for all the analyses. The samples were separated using a $100 \times 2.1 \mathrm{~mm}$ kinetex C18 column with a $2.6 \mu \mathrm{m}$ pore size (Phenomenex, Torrance, CA, USA). Isocratic elution at $50 \% \mathrm{~B}$ was run at a flow rate of $0.2 \mathrm{~mL}$ $\min ^{-1}$.

Eluent A was water-acetonitrile-formic acid (94.9:5.00:0.10 v/v/v), and eluent B was water-acetonitrile-formic acid (5:95:0.1 $v / v / v)$. The injection volume was $5 \mu \mathrm{L}$. Under these conditions, the retention time of perchlorate was $1 \mathrm{~min}$.

Mass Spectrometry: a Quattro micro API (Micromass, Manchester, UK) triple quadrupole tandem mass spectrometer operating in the MRM negative ion mode was used. Data acquisition was accomplished by MassLynx version 3.5 software (Micromass, Manchester, UK). Optimal conditions and instrument calibration are reported elsewhere [46].

\subsection{Nitrites and Nitrates Determination}

Nitrites and nitrates were determined using a Dionex DX 120 ion chromatograph (Dionex, Sunnyvale, CA, USA), equipped with an Ion Pac AS14 column $(4 \times 250 \mathrm{~mm})$. The eluent was $1.8 \mathrm{mM}$ $\mathrm{Na}_{2} \mathrm{CO}_{3}: 1.6 \mathrm{mM} \mathrm{NaHCO}_{3}$ at a flow rate of $2 \mathrm{~mL} \mathrm{~min}^{-1}$ at a pressure of $970 \mathrm{psi}$.

\subsection{DNA Procedure for Genes Analysis}

Research and sequencing of specific genes were based on DNA genomic analysis by Polymerase chain reaction (PCR). To extract genomic DNA, OGA 24 strain was inoculated in $20 \mathrm{~mL}$ of VG modified medium containing $10 \mathrm{mM}$ acetate, in aerobiosis until the exponential phase of growth. DNA was extracted as described in [47] and used in PCR experiments with specific universal primers for genes of rRNA 16S, pcrA, cld, narG, napA reported in Table S1 of Supplementary Materials. 16S rDNA was produced by primers F8 and 1525R as specified by [48] while for the other genes, heterologous and degenerate (narG-v) primers were constructed in highly conserved regions present along the coding sequences from different Proteobacteria. Databases of the National Center for Biotechnology Information (NCBI) (http://www.ncbi.nlm.nih.gov/) and Ribosomal Database Project II (RDP) (http://rdp.cme.msu.edu/) were utilized as sequence sources and the CLUSTAL W program from the European Bioinformatics Institute, Cambridge, UK (http://www.ebi.ac.uk/), for multiple sequence alignment. To improve research of the genes, different combinations of specific oligonucleotide pairs (Table S1) were utilized. All PCR reactions were performed in a $25 \mu \mathrm{L}$ reaction mixture containing approximately $20 \mathrm{ng}$ of total genomic DNA and $0.5 \mathrm{U}$ of Taq polymerase (AmpliTaq ${ }^{\circledR}$ DNA polymerase, Applied Biosystems), according to the manufacturer's instructions, as follows: 5 min of initial denaturation at $94{ }^{\circ} \mathrm{C}$, followed by 35 cycles at $94{ }^{\circ} \mathrm{C}$ for $1 \mathrm{~min}, 55-65{ }^{\circ} \mathrm{C}$ for $1 \mathrm{~min}$, and $72{ }^{\circ} \mathrm{C}$ for $1 \mathrm{~min}$. The final extension was set at $72{ }^{\circ} \mathrm{C}$ for $7 \mathrm{~min}$. Annealing temperatures were dependent on primer pairs: $55^{\circ} \mathrm{C}$ for cld-v1-ATG/cld-v2-909 and narG-v1-R/narG-v6-R; $60{ }^{\circ} \mathrm{C}$ for pcrA-v1/pcrA-v4, pcrA-v9/pcrA-v6, narG-v1-R/narG-v2-S, narG-v3-S(W)/narG-v4, narG-v3-S(W)/narG-v6-R, and napA-v1/napA-v2, napA-v3/napA-v4; $65^{\circ} \mathrm{C}$ for napA-v1/napA-v4. PCR products were separated by electrophoresis on $1 \%$ agarose gels and recovered using the Qiaex II DNA purification kit (QIAGEN) before sequence analysis. Sequencing was conducted with Sanger method by Eurofins Genomics custom DNA sequencing (http://www.eurofinsgenomics.eu/en/home/) on both strands, using primers indicated in Table S1. 16S rRNA (1495 bp), pcrA (2364 bp), cld (846 bp), and napA (526 bp) genes sequences of OGA 24 strain were deposited in the GenBank database of the National Center for Biotechnology Information (NCBI) with accession numbers GU294119 (16S), HQ697933 (pcrA), JF923467 (cld), and HQ840712 (napA). 


\subsection{Analysis of Gene Expression}

Total RNA was isolated from bacteria using RNeasy Mini Kit (QIAGEN) according to the manufacturer's instructions with $3.0 \mathrm{OD}_{600}$ of bacteria for each extraction. The RNAs were treated with DNase I (Ambion) to clear genomic DNA, and $1 \mu \mathrm{g}$ of total RNA was reverse transcribed with $100 \mathrm{U}$ Super Script III Reverse Transcriptase (Invitrogen) in a volume of $40 \mu \mathrm{L}$, using $200 \mathrm{ng}$ random hexamer primers (Roche), according to the manufacturer's instructions. The PCR reactions were optimized for the number of cycles to ensure product intensity to be within the linear range of amplification. To determine PCR linearity condition, 5 nanograms of complementary DNA (cDNA) were amplified with each pair of primers varying the number of cycles from 28 to 35 , with an increment of two cycles for each variation. Following electrophoresis of PCR amplification products, we identified the number of cycles far from the plateau conditions. Semiquantitative PCR reactions were then carried out using $5 \mathrm{ng}$ cDNA as template (except for the more expressed 16S rRNA, whose amplification was carried out using 2 pg of cDNA) and the DreamTaq enzyme (Fermentas), in a total volume of $25 \mu \mathrm{L}$, under the following conditions: one cycle at $94{ }^{\circ} \mathrm{C}$ for $5 \mathrm{~min}$, followed by $25-35$ cycles of $20 \mathrm{~s}$ at $94{ }^{\circ} \mathrm{C}, 30 \mathrm{~s}$ at $60{ }^{\circ} \mathrm{C}$, and $40 \mathrm{~s}$ at $72{ }^{\circ} \mathrm{C}$, with a final cycle at $72^{\circ} \mathrm{C}$ for $7 \mathrm{~min}$. The amounts of PCR cycles were 35 for napA, 30 for pcrA and cld, and 25 for 16S. To verify the absence of DNA template contamination a parallel, no reverse trascriptase reaction (containing all components including template RNA, except for the reverse transcriptase) was carried out for each reverse transcriptase reaction and used as a template for subsequent PCR negative controls (data not shown). 16S RNA expression was used as controls for loading. cDNAs were amplified using the specific primer pairs reported in Table S1: pcrA-OGA-RT1/pcrA-OGA-RT2, napA-OGA-RT1/napA-OGA-RT2, cld-OGA-RT1/cld-OGA-RT2, 16S-OGA-RT1/16S-OGA-RT2, for pcrA, napA, cld and 16S rRNA genes, respectively.

\subsection{Phylogenetic Analysis}

All sequences were analyzed with a similarity search utilizing the BLAST function (Basic Local Alignment Search Tool) of GenBank on the NCBI electronic site (http://www.ncbi.nlm.nih.gov/), while rDNA was analyzed by the Seq Match tool of the Ribosomal Database Project II (http://rdp. cme.msu.edu/). The phylogenetic and molecular evolutionary analysis was conducted analyzing early complete sequences present in databases using MEGA version 6 [49]; CLUSTAL W program (Cambridge, UK) was used for multiple sequence alignments; the Kimura two-parameter algorithm and the neighbor-joining method were applied for the phylogenetic tree construction. The robustness of the inferred phylogenies was determined by bootstrap analysis based on 1000 resamplings of data.

\section{Results}

\subsection{Anaerobic Perchlorate and Nitrate Utilization}

The capability of OGA 24 strain to use perchlorate was tested by kinetic studies in batch experiments. Azospira sp. OGA 24 was pre-grown aerobically in VG minimal medium containing acetate as carbon source and electron donor, and then, it was inoculated, at exponential phase in anaerobic conditions, in the fresh medium supplemented with $10 \mathrm{mM}$ acetate and $10 \mathrm{mM}$ perchlorate as the only electron acceptor. As evidenced in Figure 1A, the growth was biphasic with a slow increase of the population during the first three days followed by a rapid exponential phase. In these conditions, the bacteria population had a total of 5.3 cycles of duplication, reaching the stationary phase after about six days, with a growth rate, calculated during the faster phase, of 1.3 generations per day (Table 1 and Figure 1A). Similarly to growth, the perchlorate concentration was characterized by a slight initial reduction followed by a faster one during the second growth phase, decreasing by $70 \%$ (from $10 \mathrm{mM}$ to about $3 \mathrm{mM}$ ) after six days, with a maximum of $80 \%$ in the advanced stationary phase. 


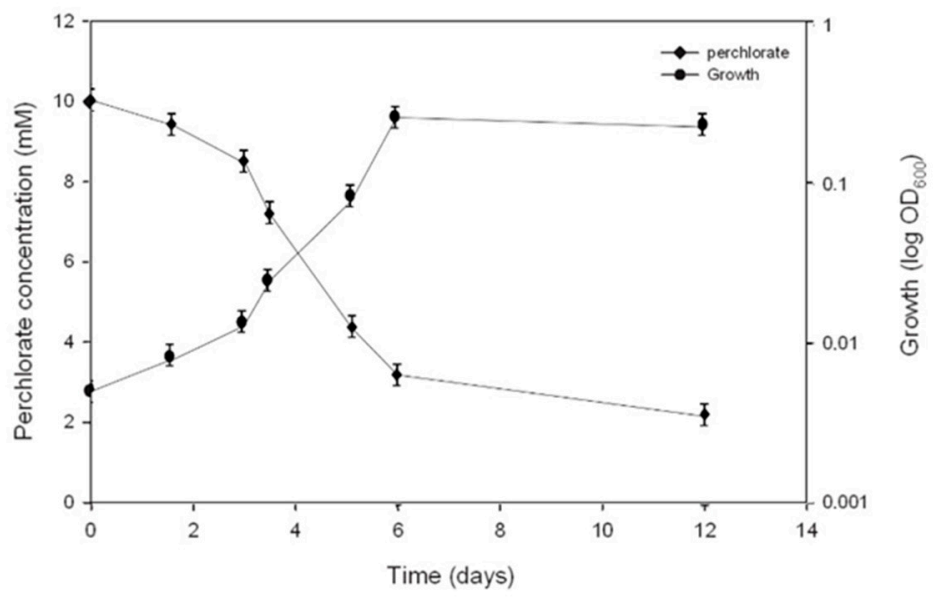

B

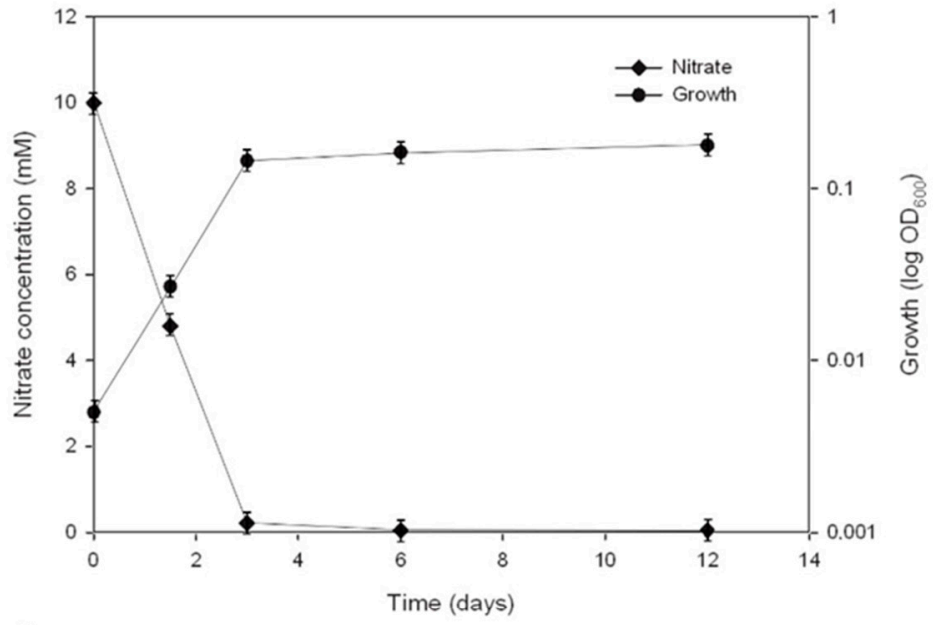

C

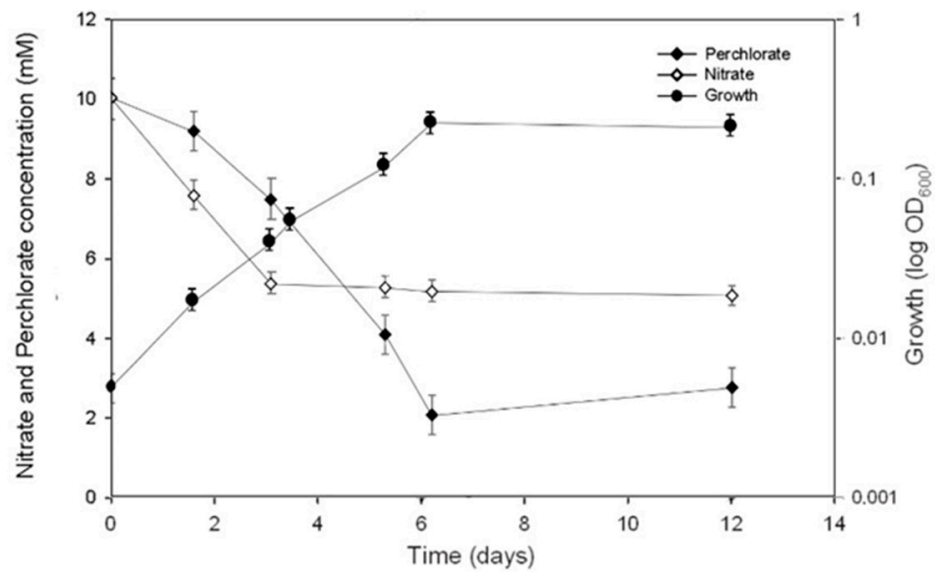

Figure 1. Growth, perchlorate and nitrate reduction. Aerobically grown strain at exponential phase was inoculated $(0.005$ OD600) under anaerobic conditions in fresh minimal medium and grown with perchlorate (A), nitrate (B) or both ions (C) as electron acceptors. Growth was monitored by OD600 measurement at indicated time. Each value represents the average of three experiments. 
Table 1. Parameters of the growth calculated in VG modified medium with $10 \mathrm{mM}$ acetate as carbon source.

\begin{tabular}{|c|c|c|c|c|c|c|}
\hline \multirow{2}{*}{ Growth Parameters } & \multicolumn{3}{|c|}{ Anaerobiosis } & \multicolumn{3}{|c|}{ Aerobiosis } \\
\hline & Perchlorate & Nitrate & Per. + Nit. & Perchlorate & Nitrate & $O x^{a}$ \\
\hline Time (days) to reach stationary phase (S. P) & 6 & 3 & 6 & 1.8 & 1.7 & 1.5 \\
\hline Biomass produced at S. P. $\left(\mu \mathrm{g} \mathrm{mL}^{-1}\right)^{\mathrm{b}}$ & $117 \pm 10$ & $114 \pm 15$ & $116 \pm 8$ & $198 \pm 12$ & $173 \pm 18$ & $197 \pm 15$ \\
\hline Growth rate (generations days ${ }^{-1}$ ) & $1.3 \pm 0.15$ & $1.6 \pm 0.20$ & $0.8 \pm 0.06$ & $3.15 \pm 0.20$ & $3.10 \pm 0.28$ & $3.62 \pm 0.22$ \\
\hline Total perchlorate reduced $\left(\mathrm{mmol} \mathrm{L}^{-1}\right)$ & $6.9 \pm 0.60$ & / & $7.2 \pm 0.50$ & $5.6 \pm 0.34$ & / & 1 \\
\hline Total nitrate reduced $\left(\mathrm{mmol} \mathrm{L}^{-1}\right)$ & / & $9.8 \pm 0.15$ & $4.9 \pm 0.40$ & / & $9.7 \pm 0.22$ & l \\
\hline Specific consumption $\left(\mathrm{nmol} \mu \mathrm{g}^{-1}\right.$ cells) ${ }^{\mathrm{b}}$ & $59 \pm 2.6$ & / & $62 \pm 2.2$ & $11 \pm 1.6$ & / & / \\
\hline Perchlorate nitrate & / & $86 \pm 4.3$ & $42 \pm 2.4$ & / & $51 \pm 2.1$ & l \\
\hline Chlorate accumulation in S. P. $\left(\mathrm{mmol} \mathrm{L}^{-1}\right)$ & ud & / & ud & $3.5 \pm 0.2$ & / & l \\
\hline Nitrite accumulation in S.P. $\left(\mathrm{mmol} \mathrm{L}^{-1}\right)$ & l & ud & ud & / & ud & / \\
\hline
\end{tabular}

${ }^{a}$ Growth in aerobiosis, without either perchlorate or nitrate. ${ }^{b}$ Biomass are reported as dry weight. ud: undetectable in the medium. The values are reported as average of three determinations \pm SD.

In the presence of nitrate as the only acceptor, the bacterium reached the stationary phase faster than with perchlorate (three days) and reduced the nitrate concentration by more than $99 \%$ (from $10 \mathrm{mM}$ to about $0.22 \mathrm{mM}$ ) (Figure 1B and Table 1). Total generations and biomass produced were similar to those observed with perchlorate and the average growth rate was 1.6 days $^{-1}$. Kinetic data on nitrate utilization are in agreement with a previous study where, by a suitably designed reactor, we characterized the ability of OGA 24 to denitrify [43].

The effects of simultaneous presence of perchlorate and nitrate were also evaluated. As showed in Figure 1C, growth kinetics was similar to that observed with only perchlorate as it reached stationary phase after about six days, but the slow phase in the first three days was not evident. Final biomass was not changed by the co-presence of acceptors (Figure 1 and Table 1). The kinetics of perchlorate utilization was comparable to that observed without nitrate; on the contrary, the kinetics of nitrate was very influenced by perchlorate. In fact, total decrease of nitrate at the end of exponential phase was only $50 \%$ compared to the $99 \%$ observed without perchlorate, and it occurred almost completely in the first three days of growth (Table 1). In all experimental conditions for the entire duration of the kinetic tests, no value of chlorate concentration, as product of perchlorate reduction, was ever detected in the medium.

\subsection{Respiratory Nitrate Reductase Genes}

In order to throw light into the mechanism which regulates the use of nitrate and perchlorate in the strain Azospira sp. OGA 24, the presence of genes involved in nitrate respiration was first assessed, focusing on periplasmic nitrate reductase (Nap), since we had already demonstrated in a previous study the absence of membrane nitrate reductase (Nar) [42]. Several pairs of specific heterologous and degenerate primers (Table S1, Supplementary Materials) were constructed on proteobacterial conserved regions present along the coding sequences of the large subunit of periplasmic nitrate reductase (napA) and tested by PCR analysis. As evidenced in Figure 2, napA gene was specifically amplified. Partial fragment nap-v3/4 (526 pb) was sequenced, and the sequence deposited at GenBank of National Centre for Biological Information with accession numbers HQ840712.

\subsection{Expression Analysis of pcrA and napA Genes}

Successively, we assessed the regulation of mRNA expression of $p c r \mathrm{~A}$, napA, and cld genes from oxygen, nitrate, and perchlorate. Azospira strain OGA 24 was grown in VG medium with acetate in aerobic condition up to the middle of the exponential phase; then, an aliquot of cell culture was used directly for total RNA extraction, while a second one was inoculated into fresh VG medium containing either or both nitrate and perchlorate and growth anaerobically up to middle of exponential phase before RNA extraction. Expression analysis was performed by semi-quantitative RT-PCR. In anaerobiosis, nap A and pcrA genes were induced by the correspondent compounds, with nap A mRNA absent when perchlorate was the only electron acceptor and pcrA mRNA barely detectable in 
nitrate reducing conditions (Figure 3), indicating a pathway separation for two reduction processes, at least at terminal reductases level. With both acceptors, perchlorate greatly reduced the nitrate reductase expression, while that of pcrA was unaffected by nitrate, in accordance with kinetic data (Figure 1C). In aerobic conditions, both pcrA and napA genes were expressed, but unlike napA, pcrA was further induced under anaerobic conditions with perchlorate, also in association with nitrate.

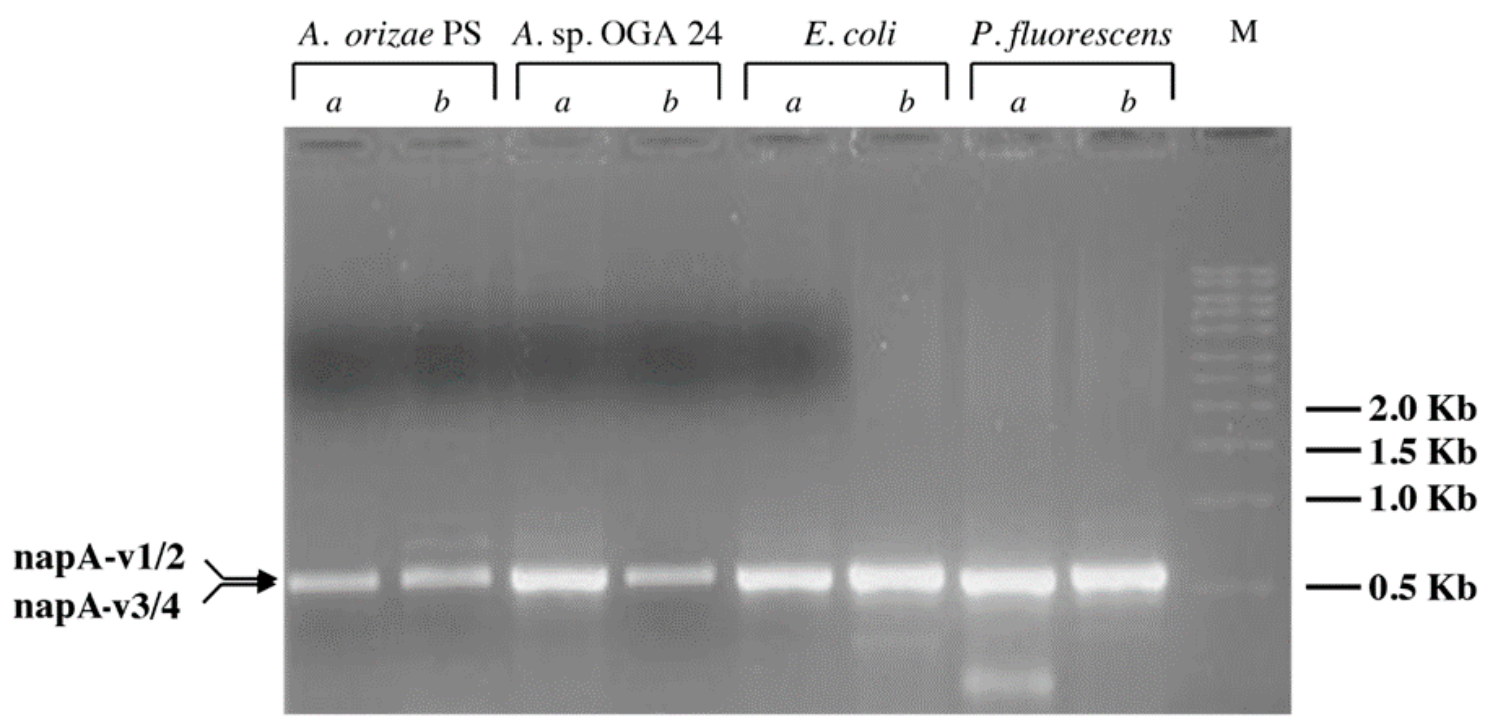

Figure 2. PCR analysis of large subunit of periplasmic nitrate reductase (napA). Lanes $a$ and $b$ indicate amplification by nap-v $1 / 2$ and nap-v 3/4, respectively. M: molecular marker. Escherichia coli, Pseudomonas fluorescens, and A. oryzae PS were used as positive control. Expected length for PCR fragments: $591 \mathrm{bp}$ for nap-v $1 / 2$ and $541 \mathrm{bp}$ for nap-v 3/4.
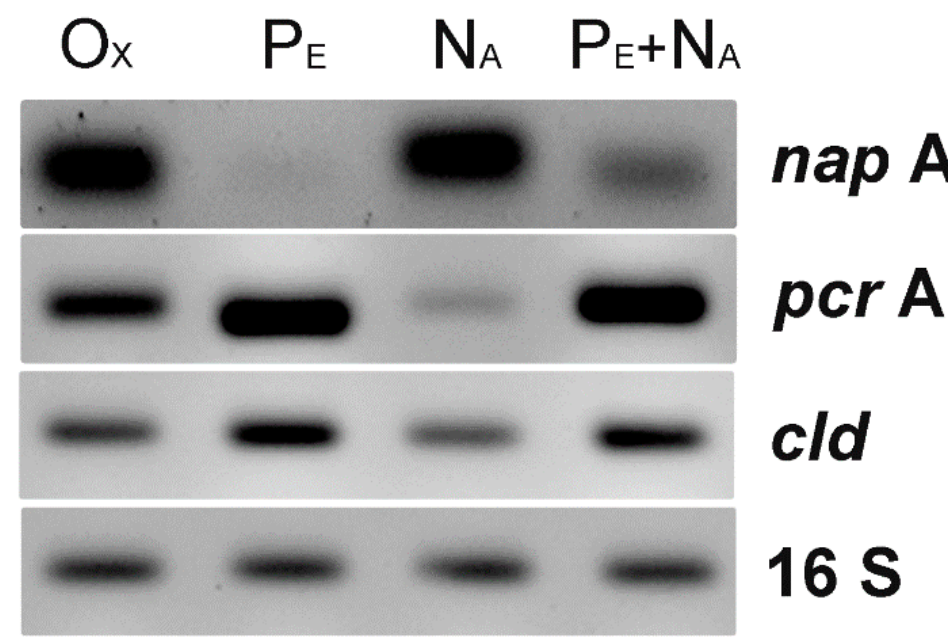

Figure 3. Expression analysis by RT-PCR. mRNAs expression was evaluated in VG medium containing $10 \mathrm{mM}$ sodium acetate as carbon source. At exponential phase cells grown in aerobiosis (Ox) with oxygen as only electron acceptor were inoculated in anaerobic conditions at the presence of perchlorate $(\mathrm{PE})$, nitrate (NA), and both perchlorate and nitrate (PE + NA) as electron acceptors. 16S rRNA expression was used as control for loading. The analysis was performed in triplicate with similar results. A typical experiment is shown.

Analysis of cld gene expression was in accordance with pcrA regulation in this strain, with a basal activation in aerobiosis conditions and a further stimulation by perchlorate in anaerobiosis; however, differently from $\operatorname{pcr} \mathrm{A}$, in the presence of nitrate as the only electron acceptor, it was expressed at similar levels compared to the aerobic conditions. 
Expression data showed that in Azospira sp. OGA 24, there are two distinct pathways for perchlorate and nitrate respiration, each induced in anaerobiosis by the respective electron acceptor, and that the key enzymes of the two pathways are expressed also in aerobiosis.

\subsection{Aerobic Perchlorate and Nitrate Respiration}

Expression data indicated the possible presence of perchlorate and nitrate reduction activities in aerobiosis (Figure 3). In order to verify such a possibility, kinetic tests were performed in VG medium in presence of oxygen, $10 \mathrm{mM}$ acetate, and $10 \mathrm{mM}$ either nitrate or perchlorate. An only-acetate control was also inserted. As reported in Figure 4 and in Table 1, in these experimental conditions, both anions were efficiently reduced with a perchlorate and nitrate consumption of $5.6 \mathrm{mmol} \mathrm{L}^{-1}$ and more than $9.7 \mathrm{mmol} \mathrm{L}^{-1}$, respectively, measured at the entrance in stationary phase. In aerobiosis, perchlorate reduction was accompanied by accumulation of chlorate $\left(3.5 \mathrm{mmol} \mathrm{L}^{-1}\right)$, while after the reduction of nitrate, $\mathrm{N}_{2} \mathrm{O}$ was developed, and nitrite was undetectable, indicating an aerobic denitrification. The presence of functionally active perchlorate reductase in aerobiosis was also confirmed by evaluating the growth in the presence of chlorate. Under these conditions at the beginning of the stationary phase, the concentration of the latter was reduced from $10 \mathrm{mM}$ to $6.5 \mathrm{mM}$.

\section{A}

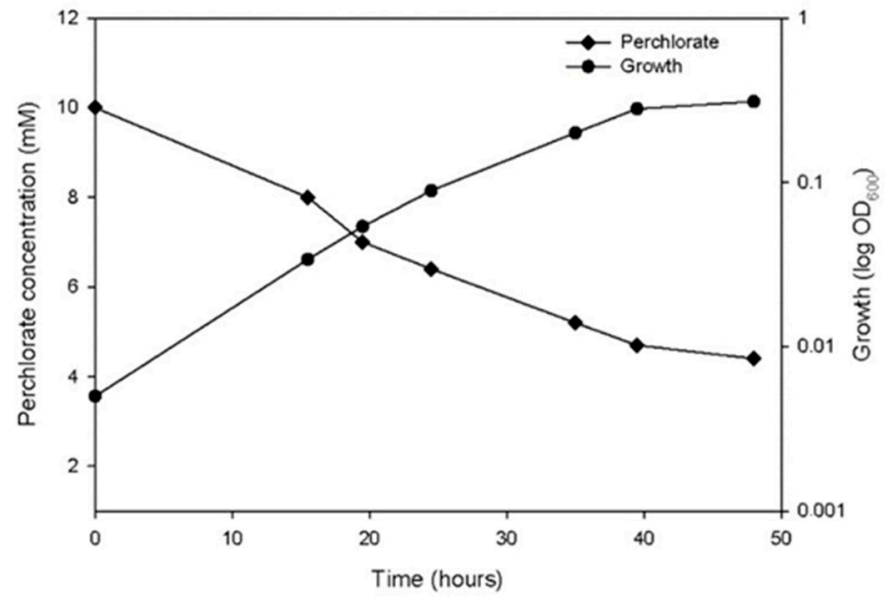

B

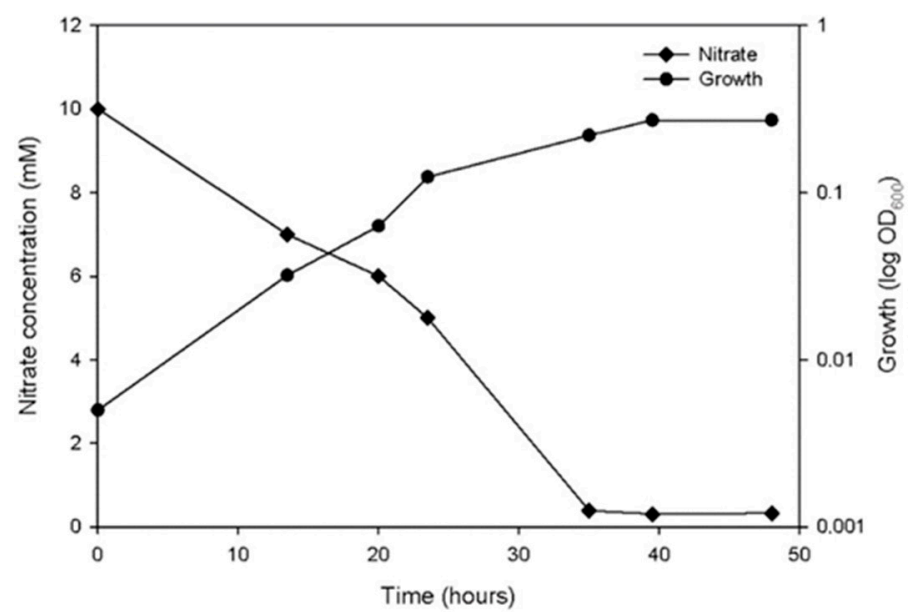

Figure 4. Aerobic perchlorate and nitrate utilization. Aerobically grown strain at exponential phase was inoculated at 0.005 OD600 in fresh minimal medium in aerobiosis at presence of either perchlorate (A) or nitrate (B), and kinetics of the growth and perchlorate/nitrate utilization were calculated. Each value represents the average of three experiments. 
As a conclusion of this analysis, results of anaerobic and aerobic conditions were compared (Table 1). In aerobiosis, specific consumptions ( $\mathrm{nmol} \mu \mathrm{g}^{-1}$ dry cell weight) of perchlorate (net of chlorate accumulation) and nitrate were about 5 and 1.5 times, respectively, lower than that measured under anoxic conditions. As expected, for facultative anaerobes [50], the growth was favored in the presence of oxygen. The growth rates, comparable at the presence of either perchlorate or nitrate, were respectively more than 2.4 and 1.9 times higher than the corresponding rates evaluated in anaerobic conditions. Similarly, final biomass was approximately 1.7 times higher for cells grown both in perchlorate and nitrate. By considering positive effects of oxygen on the growth, the decrease on nitrate measured in one liter of medium was similar to that in anoxic conditions (about $9.7 \mathrm{mmol} \mathrm{L}^{-1}$ ), while that of perchlorate was 1.2 times lower $\left(5.6 \mathrm{vs}\right.$. $\left.6.9 \mathrm{mmol} \mathrm{L}^{-1}\right)$, with a complete reduction to chloride of about $2 \mathrm{mmol} \mathrm{L}^{-1}$ (net of chlorate accumulation). Under aerobic conditions, growth with only acetate produced biomass comparable to that of samples grown in the presence of perchlorate or nitrate; however, the growth rate was slightly higher, and the times to reach the stationary phase were shorter.

\subsection{Taxonomic Characterization of OGA 24}

On the basis of the sequence of $16 \mathrm{~S}$ rDNA strain, OGA 24 was previously identified as Azospira genus [42]. Here, we further characterized this strain molecularly at species level through a comparative analysis based on the sequences of $16 \mathrm{~S}$ perchlorate reductase alpha subunit ( $p c r \mathrm{~A})$, chlorite dismutase ( $c l d$ ), and periplasmic nitrate reductase large subunit (napA) (GenBank numbers GU294119, HQ697933 JF923467, and HQ840712, respectively). Blast search by the almost full-length $16 \mathrm{~S}$ rDNA (1495 bp) confirmed that strain OGA 24 is a $\beta$-proteobacterium belonging to Azospira genus (syn. Dechlorosoma) $[15,16,51]$. The closest relative was Dechlorosoma sp. PCC, $100 \%$ identity of $16 \mathrm{~S}$ rDNA (1511 bp, GenBank no. AY126453), while at species level the nearest strains were Azospira oryzae 6a3 ${ }^{\mathrm{T}}$ (1436 bp, AF011347), Azospira oryzae PS (syn. Dechlorosoma suillum PS) (1532 bp, AF170348) and Azospira oryzae GR-1 (1486 bp, AY277622), with 99.9\%, 99.9\%, and 99.7\% of identity, respectively. Comparison with Azospira restricta SUA2 ${ }^{\mathrm{T}}$, another characterized species included in this genus [52] resulted in $96.5 \%$ of identity, below accepted molecular limits for species definition ( $\geq 97.5 \%)$ [53]. The phylogenetic analysis based on $16 \mathrm{~S}$ rDNA clearly indicated the relationship of identified strain with Rhodocyclaceae family of $\beta$-proteobacteria, placing strain OGA 24 within the group of oryzae species (Figure 5), in accordance with phylogenetic characteristics reported by [51]. High value of bootstrap also supported separation of OGA 24 strain from A. restricta species (Figure 5B).

Blast analysis of nearly full coding sequence $(2364 \mathrm{bp})$ of alpha subunit of perchlorate reductase indicated that the closest genes were those of Dechlorosoma sp. PCC (2206 bp, EU022027) and Dechloromonas sp. PC1 (2206 bp, EU022026), both with 99\% identity at DNA level and 99\% of identity at level of translate proteins. In addition to pcrA of Dechloromonas sp PC1, the closest sequences of phylogenetically distinct Dechloromonas genus were molybdopterin oxidoreductase of Dechloromonas aromatica RCB (2784 pb, YP285785.1) and alpha subunit of perchlorate reductase of Dechloromonas agitata $\mathrm{CKB}^{\mathrm{T}}$ (full coding sequence of $2784 \mathrm{pb}, \mathrm{AY} 180108$ ), respectively, with DNA sequences identity of $80 \%$ and $76 \%$ and of $91 \%$ and $82 \%$ at protein level ( $97 \%$ and $92 \%$ of homology). The phylogenetic analysis of PcrA of the OGA 24 indicated a relationship with PcrA of Azospira genus (Dechlorosoma sp. PCC); however, it did not show a distinct clustering in Azospira or Dechloromonas genus (Figure 6A).

The closest sequences ( $846 \mathrm{bp}$ ) for chlorite dismutase were those of Azospira oryzae GR-1 (full coding sequence of $849 \mathrm{bp}, \mathrm{GU} 003876)$, Dechlorosoma sp. KJ (849 bp, EU571095) and Azospira oryzae PS (849 pb, AY540960), respectively with 96\%, 96\%, and 95\% identity at DNA level and 99\%, 99\%, and $98 \%$ identity at protein level $(99.3 \%, 99.3 \%$, and $98.9 \%$ homology). The closest chlorite dismutase sequences of Dechloromonas genus were those of Dechloromonas sp. MissR (849 bp, GU003878) and Dechloromonas hortensis DSM 15637 strains (849 pb, EU436749), both with 92\% identity at DNA level 
and $96 \%$ at protein level (98\% homology). Phylogenetic analysis evidenced a distinct clusterization of Cld enzyme of OGA 24 within Azospira oryzae group (Figure 6B).
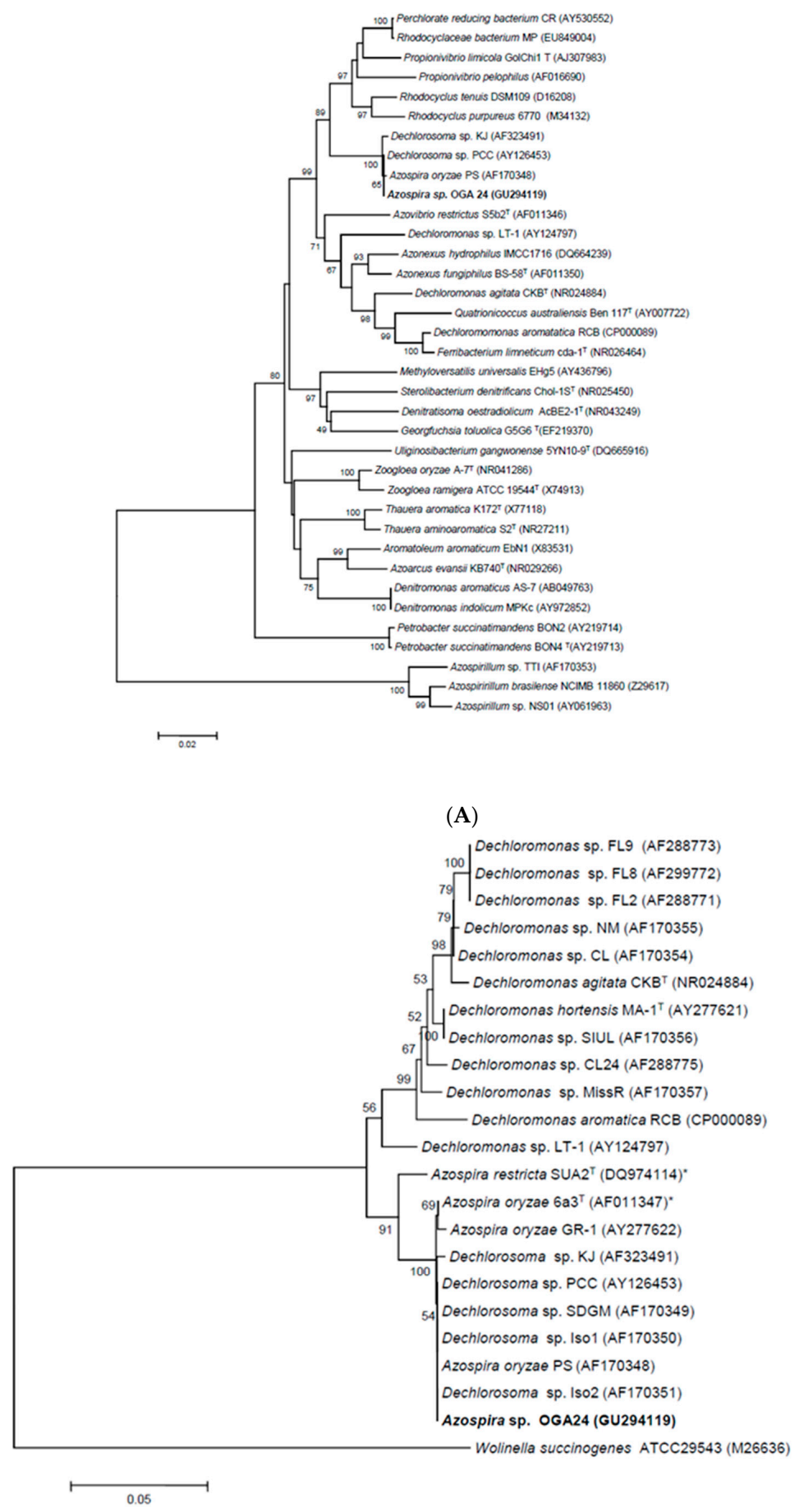

(B)

Figure 5. Phylogenetic analysis based on $16 \mathrm{~S}$ rDNA sequences. Relationship of OGA 24 strain with Rodociclacea family of $\beta$-Proteobacteria (A) and with Azopira oryzae species (B). For the analysis, only nearly complete sequence (>1300 pb) were considered. In bold Azospira sp. OGA 24 , in brackets GenBank accession numbers of the sequences. In (B) asterisk indicate species not perchlorate reducing. Wolinella succinogenes ATCC 29543 ( $\varepsilon$-Proteobaterium) was introduced as an example of unrelated PRB proteobacterium. Bootstrap values (expressed as percentages of 1000 replications) $>50$ are shown at branching points. 
(A)

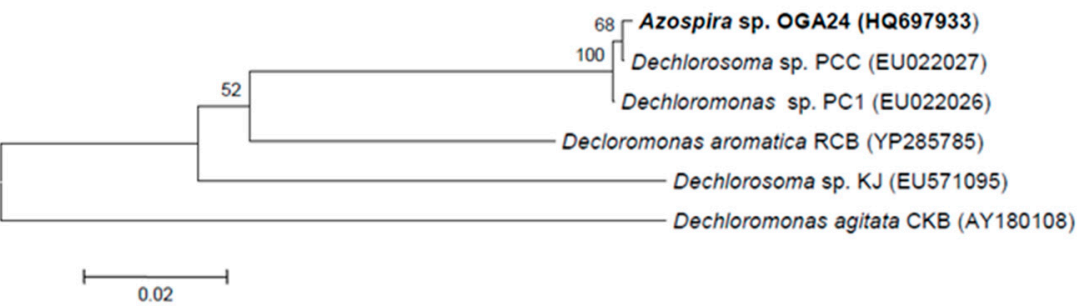

(B)

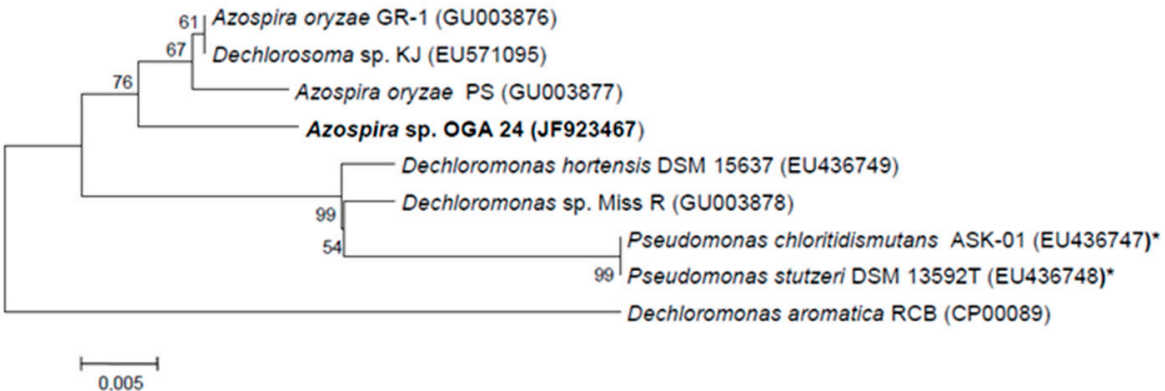

Figure 6. Phylogenetic analysis of perchlorate reductase and chlorite dismutase. Relationship of PcrA (A) and Cld (B) of OGA 24 strain (bold) with correspondent amino acids sequences of related Proteobacteria are indicated. In $(\mathbf{B})$ both PRB and CRB $\left({ }^{*}\right)$ are reported. For the analysis, only coding sequences present in database $>2000 \mathrm{bp}$ and $>800 \mathrm{bp}$ for PcrA and Cld, respectively, were considered. Bootstrap values (expressed as percentages of 1000 replications) $>50$ are shown.

Finally, we extended blast analysis to partial coding region (526 pb) of periplasmic nitrate reductase large subunit (GenBank no HQ840712). Among PRBs, the closest relatives were napA genes of Azospira oryzae PS (HQ840711) and Dechloromonas aromatica RCB (CP000089), with identity at DNA level of $98 \%$ and $79 \%$ and at protein level of $99 \%$ (100\% homology) and 75\% (89\% homology), respectively. The closest relative strains unable to respire perchlorate were Magnetospirillum magneticum AMB-1 (AP007255) and Pseudomonas aeruginosa PA7 (CP000744). In these bacteria, the napA genes had a greater identity than those of Dechloromonas aromatic RCB but a lower identity at peptide level, $82 \%$ and $80 \%$ at DNA level and 74\% (85\% homology) and 75\% (84\% homology) at peptide level, respectively. The stronger relationship with the NapA of Azospira oryzae PS strain further confirmed the belonging to the oryze species.

\section{Discussion}

\subsection{Role of Oxygen on Perchlorate Respiration Pathway}

Most of PRB are facultative anaerobes with few microaerophilic strains [20,54], and oxygen is utilized preferentially with respect to perchlorate, due to higher released energy $\left(\Delta \mathrm{G}^{\mathrm{o}}=-1844 \mathrm{~kJ}\right.$ mol acetate $\left.{ }^{-1}\right)$ respect to dissimilation of perchlorate $\left(\Delta \mathrm{G}^{\mathrm{o}}=-801 \mathrm{~kJ}\right.$ mol acetate $\left.{ }^{-1}\right)$. Aerobic conditions inhibit the enzymes of perchlorate respiration, while anaerobiosis and perchlorate (or chlorate) are both required for their activation $[20,23,25,29,34,45]$. These regulatory aspects have been described in different PRB strains. For Azospira oryzae PS the dissolution of oxygen $\left(2 \mathrm{mg} \mathrm{L}^{-1}\right)$ during anoxic growth caused inhibition of perchlorate consumption and reduction of chlorite dismutase activity. In anaerobiosis Cld activity was only detected in the presence of perchlorate, and in aerobiosis it was not inducible [34]. In Dechloromonas agitata CKB, the gene of alpha subunit of perchlorate reductase was induced under anaerobic conditions in the presence of either chlorate or perchlorate, while expression was completely inhibited by oxygen [27]. Cld enzyme was only expressed in anaerobiosis in the presence of perchlorate [55]. Azospira sp. KJ, grown aerobically, when transferred under perchlorate-reducing conditions entered in a lag periods of 2 days before the growth started 
again using perchlorate ( 0.3 days for chlorate), and in anaerobiosis, chlorite dismutase activity was induced specifically by perchlorate and chlorate [33].

In this study, differently from previously well characterized PRB, we identified a strain that in aerobiosis presents activated pathway of perchlorate respiration, as shown by mRNA analysis of the genes pcrA and cld and by aerobic consumption of perchlorate and chlorate. The pathway is not constitutive since in anaerobic conditions it is up regulated specifically by perchlorate, as evidenced by expression of both pcrA and cld genes after the switching from aerobiosis to perchlorate-, but not nitrate-, reducing conditions (Figures 1 and 3 ).

Aerobic perchlorate dissimilation has been reported for some strains isolated from soil of South India and identified by $16 \mathrm{~S}$ rDNA as belonging to genus Pseudomonas and to more phylogenetically distant Gram positive Arthrobacter [56]. All strains are fermentative, incapable of anaerobic respiration and do not have nitrate-reducing activity, showing metabolic characteristics completely different from those of the PRB. Furthermore, perchlorate reductase so far characterized are molybdenum-dependent $[34,41]$, and the authors reported that in isolated strains perchlorate consumption was a molybdenum-independent process, suggesting that different reductases are involved.

\subsection{Nitrate Reduction and Relationship with Perchlorate Pathway}

Almost all described PRB can grow oxidizing acetate by a denitrification pathway $[17,21,24,38]$, and since the energy yield is comparable with respect to perchlorate dissimilation $\left(\Delta \mathrm{G}^{\mathrm{o}}=-792 \mathrm{~kJ} \mathrm{~mol} \mathrm{acetate}{ }^{-1}\right.$ and $\Delta \mathrm{G}^{\mathrm{o}}=-801 \mathrm{~kJ} \mathrm{~mol} \mathrm{acetate}{ }^{-1}$, respectively) [57], nitrate and perchlorate are potential competitors. Except few cases [26,58,59], an inhibitory effect of nitrate reduction on that of perchlorate has been reported, but mechanisms of this regulation and molecular relationships between the two pathways are still not well known. In this scenario, a further complication is given by the ability of some (per)chlorate- and nitrate-reductases to recognize nitrate and perchlorate, as substrate analogues [25,33,41]. D. agitata CKB [34], Wolinella succinogenes HAP-1 [35] and Perc1ace [40] can reduce nitrate and perchlorate simultaneously, but only Perclace can develop with nitrate. The growing rate of $D$. agitata at the contemporary presence of perchlorate and nitrate ions and the extent of perchlorate utilization were slightly lower than those observed without nitrate and accumulation of nitrite in medium was detected. The nitrite accumulation was ascribed to the ability of the perchlorate reductase to recognize also nitrate as substrate [34,37]. Perchlorate reductase purified from Azospira oryzae GR-1 strain was also able to reduce nitrate [39]. Relevant inhibitory effects of nitrate dissimilation were observed in the case of Dechlorospirillum anomalous JB116 [60] and Azospira aryzae PS. This latter can grow with nitrate whereas, when both compounds are present, perchlorate utilization starts only after the complete removal of nitrate [34,39]. In accordance, chlorite dismutase activity was not found in the presence of nitrate. Several evidences have suggested for this strain two separate pathways for perchlorate and nitrate respiration [34,37,39]. Distinct pathways were also described in Azospira sp. KJ [33], Dechloromonas aromatica RCB, and Perc1ace. In the case of D. aromatica RCB, perchlorate grown cells reduced both perchlorate and nitrate with nitrite accumulation, but nitrate grown cells only reduced nitrate. In Perclace either nitrate or perchlorate stimulated reduction of both compounds, and the presence of separate terminal reductases, each with both nitrate and perchlorate reduction activity, was reported [40]. On the basis of these experimental observations, it is possible to affirm that molecular relationship and co-regulation of nitrate and perchlorate respiration pathways are highly variable and depending on the isolated bacterial species. The OGA 24 strain can grow in the presence of nitrate as only electron acceptor, through denitrification mediated by periplasmic nitrate reductase (Nap). Expression analysis of nap A and pcrA genes in accordance to kinetic results (Figure 1) indicated a separation of perchlorate and nitrate respiration pathways at least to level of upstream reductases (Figure 3). The strain can reduce nitrate and perchlorate simultaneously, but the extent and the rate of nitrate respiration are significantly decreased by equimolar levels of perchlorate, while perchlorate consumption results unaffected by nitrate presence. Expression analysis displayed a 
similar trend, showing that inhibitory action of perchlorate is carried out transcriptionally by reducing production of napA mRNA. A functionally active periplasmic nitrate reductase has also been described for Azospira oryzae PS [39]; the partial sequence of the coding region of its napA gene (accession number HQ840711) was deposited in GenBank of NCBI. Differently from OGA 24 in PS strain and other described PRB, nitrate utilization is prevalent on that of perchlorate [20,34], indicating a different regulation of Nap-dependent denitrification pathway and, consequently, a different application potential [39]. Azospira sp. OGA 24, to our knowledge, is the first characterized environmental perchlorate-reducing bacteria in which nitrate respiration pathway is down regulated by perchlorate and not vice-versa.

The nitrate dissimilation pathway is inhibited by oxygen and activated by nitrate in anaerobic conditions, both in nitrate and perchlorate respiring bacteria [33,39]. However, this behavior is common for pathways that use membrane bound nitrate reductase (Nar) [61]. In a previous study based on molecular analysis, we showed that OGA 24 lacks gene coding for catalityc $\alpha$ subunity (NarG) of membrane bound nitrate reductase [42]; therefore, in this bacterium, the regulation of denitrification is strictly dependent on Nap. With periplasmic nitrate reductase systems, more variable regulation is possible [62,63]. Normally, Nap enzymes are not affected by oxygen, and some denitrifiers perform aerobic denitrification coupling Nap to nitrite and N-oxide reductases [62-64]; moreover, both nitrate-dependent and -independent expression of periplasmic nitrate reductase have been observed [65-67]. In accordance to the presence of napA gene and with its expression, we found that Azospira sp. OGA 24 is capable of aerobic denitrification, but as for perchlorate pathway, denitrification pathway is not constitutive, and in anaerobiosis, it results strictly nitrate-dependent (Figure 3).

\subsection{Chlorite Dismutase}

Another regulatory aspect concerns the chlorite dismutase that in nitrate-reducing conditions and without perchlorate was expressed at levels similar to those of aerobiosis (Figure 3). At this stage of our study, we do not know if in nitrate-reducing conditions OGA 24 presents an active Cld or if further regulatory processes take place after transcription; however, a variable regulation of chlorite dismutase has been commonly reported for chlorate reducing bacteria (CRB) $[26,33,34]$, and some evidence could also exist for PRB [33]. This suggests that the chlorite dismutase may be involved in other functions of energetic metabolism, and a role has been proposed in oxygen production for aerobic degradation of different substrates in anaerobic conditions [68,69]. At support of alternative functions, a putative Cld gene was identified in the genome of Magnetospirillum magnetotacticum, a not (per)chlorate growing bacteria closely related to PRB Dechlorospirillum anomalous [70,71], and chlorite dismutase-like enzymes were reported from other different not (per)chlorate respiring microorganisms [72,73].

\subsection{Taxonomic Analysis}

$16 \mathrm{~S}$ rRNA gene indicated a clusterization of strain OGA 24 in Azospira genus (99.7-100\% identity), among Azoarcus, Thauera and Rhodocyclus genera of Rhodociclaceae family as described for this bacterial group [51] and in oryza species (99.7-99.9\% identity with characterized species). These genetic relationships were confirmed by analysis of chlorite dismutase (Cld), large subunit of periplasmic nitrate reductase (NapA), and partially alpha subunit of perchlorate reductase (PcrA). Phylogenetic analysis of Cld based on amino acid sequences was in accordance with 16S rRNA results, whereas for PcrA, it indicated a relationship with Azospira genus, but it did not show a distinct clustering in this taxon. This latter aspect was not in contrast with taxonomic results, as suggested by different studies that hypothesize that the metabolic capability to grow by the dissimilation of perchlorate is the result of a horizontal gene transfer $[17,36,74]$. Therefore, based on the molecular results and the high identity value of the 16S rDNA, above the molecular limits accepted for the definition of the species [53], we suggest that the Azospira OGA 24 strain should be included in the oryzae species. 


\section{Conclusions}

Environmental perchlorate-reducing bacteria have evolved various strategies to regulate respiration of perchlorate and nitrate. In this study, we characterize a strain isolated from a highly polluted river by enrichment method and report a different strategy than those described so far. Azospira sp. OGA 24 has the unique feature to have a pathway of perchlorate not down-regulated by nitrate, and it is able to respire perchlorate and nitrate also in aerobiosis. These aspects, together with the high tolerance to perchlorate (up to $100 \mathrm{mM}$, both in anoxic and aerobic conditions), make it very attractive in terms of potential applications in bioremediation programs, considering that nitrate is almost always present in contaminated environments and at concentrations of several orders of magnitude compared to that of perchlorate, and generally, it represents the main obstacle to biological decontamination.

Supplementary Materials: The following is available online at http://www.mdpi.com/2073-4441/12/8/2220/s1. Table S1: List of Oligonucleotide primers used in this study.

Author Contributions: Individual contributions to this study were as follows: Conceptualization, O.M., G.V. and A.P.; methodology, G.V., A.P., M.T.; investigation, F.G., M.T.; data curation, F.G. and O.M.; writing—original draft preparation, G.V.; writing—review and editing, G.V., O.M., A.P.; supervision, O.M., A.P., G.V.; project administration, O.M., G.V., A.P.; funding acquisition, G.V., A.P., O.M. All authors have read and agreed to the published version of the manuscript.

Funding: This work was supported by MIUR-FARB 2017-2019 funding from Università di Salerno.

Acknowledgments: The authors would like to thank Mario Felice Tecce and Ylenia Miele (University of Salerno) for their valuable advice in preparing the manuscript.

Conflicts of Interest: The authors declare no conflicts of interest.

\section{References}

1. Orris, G.J.; Harvey, G.J.; Tsui, D.T.; Eldrige, J.E. Preliminary Analyses for Perchlorate in selected Natural Materials and Their Derivatives Products; USGS Open-FileReport03-314; USGS, US Government Printing Office: Washington, DC, USA, 2003.

2. Dasgupta, P.K.; Martinelango, P.K.; Jackson, W.A.; Anderson, T.A.; Tian, K.; Tock, R.W.; Rajacopalan, S. The origin of naturally occurring perchlorate: The role of atmospheric processes. Environ. Sci. Technol. 2005, 39, 1569-1575. [CrossRef] [PubMed]

3. Parker, D.R.; Seyfferth, A.L.; Reese, B.K. Perchlorate in groundwater: A synoptic survey of "Pristine" Sites in the Coterminous United States. Environ. Sci. Technol. 2008, 42, 1465-1471. [CrossRef] [PubMed]

4. Kumarathilaka, P.; Oze, C.; Indraratne, S.P.; Vinthanage, M. Perchlorate as an emerging contaminant in soil, water and food. Chemosphere 2016, 150, 667-677. [CrossRef]

5. Crump, C.; Michaud, P.; Téllez, R.; Reyes, C.; Gonzalez, G.; Montgomery, E.L.; Crump, K.; Lobo, G.; Becerra, C.; Gibss, J. Does perchlorate in drinking water affect thyroid function in new borns or school-age children? J. Occup. Environ. Med. 2000, 42, 603-612. [CrossRef] [PubMed]

6. Tran, N.; Valentin-Blasini, L.; Blount, B.C.; McCuistion, C.G.; Fenton, M.S.; Gin, E.; Salem, A.; Hershman, J.M. Thyroid-stimulating hormone increases active transport of perchlorate into thyroid cells. Am. J. Physiol. Endocrinol. Metab. 2008, 294, E802-E8066. [CrossRef] [PubMed]

7. Maffini, M.V.; Trasande, L.; Neltner, T.G. Perchlorate and Diet: Human Exposures, Risks, and Mitigation Strategies. Curr. Environ. Health Rep. 2016, 3, 107-117.

8. Knight, B.A.; Shields, B.M.; He, X.; Pearce, E.N.; Braverman, L.E.; Sturley, R.; Vaidya, B. Effect of perchlorate and thiocyanate exposure on thyroid function of pregnant women from South-West England: A cohort study. Thyroid. Res. 2018, 11, 9. [CrossRef]

9. Smith, S.M.; Vale, W.W. The role of the hypothalamic-pituitary-adrenal axis in neuroendocrine responses to stress. Dialogues Clin. Neurosci. 2006, 8, 383-395.

10. Steinmaus, C.; Pearl, M.; Kharrazi, M.; Blount, B.C.; Miller, M.D.; Pearce, E.N.; Valentin-Blasini, L.; DeLorenze, G.; Hoofnagle, A.N.; Liaw, J. Thyroid hormones and moderate exposure to perchlorate during pregnancy in women in southern California. Environ. Health Perspect. 2016, 124, 861-867. [CrossRef]

11. Urbansky, E.T. Perchlorate as an environmental contaminant. Environ. Sci. Pollut. Res. Int. 2002, 9, 187-192. [CrossRef] 
12. Zhu, Y.; Gao, N.; Chu, W.; Wang, S.; Xu, J. Bacterial reduction of highly concentrated perchlorate: Kinetics and influence of co-existing electron acceptors, temperature, $\mathrm{pH}$ and electron donors. Chemosphere 2016, 148, 188-194. [CrossRef] [PubMed]

13. Urbansky, E.T. Perchlorate chemistry: Implications for analysis and remediation. Bioremediat. J. 1998, 2, 81-95. [CrossRef]

14. Melnyk, R.A.; Coates, J.D. The Perchlorate Reduction Genomic Island: Mechanisms and Pathways of Evolution by Horizontal Gene Transfer. BMC Genom. 2015, 16, 862. [CrossRef] [PubMed]

15. Tan, Z.; Reinhold-Hurek, B. Dechlorosoma suillum Achenbach et al. 2001 is a later subjective synonym of Azospira oryzae Reinhold-Hurek and Hurek 2000. Int. J. Syst. Evol. Microbiol. 2003, 53, 1139-1142. [CrossRef]

16. Wolterink, A.; Kim, S.; Muusse, M.; Kim, I.S.; Roholl, P.J.M.; van Ginkel, C.G.; Stams, A.J.M.; Kengen, S.W.M. Dechloromonas hortensis sp. nov. and strain ASK-1, two novel (per)chlorate-reducing bacteria, and taxonomic description of strain GR-1. Int. J. Syst. Evol. Microbiol. 2005, 55, 2063-2068. [CrossRef]

17. Achenbach, L.A.; Michaelidou, U.; Bruce, R.A.; Fryman, J.; Coates, J.D. Dechloromonas agitata gen. nov., sp. nov. and Dechlorosoma suillum gen. nov., sp. nov., two novel environmentally dominant (per)chlorate-reducing bacteria and their phylogenetic position. Int. J. Syst. Evol. Microbiol. 2001, 51, 527-533. [CrossRef]

18. Dudley, M.; Salamone, A.; Nerenberg, R. Kinetics of a chlorate-accumulating, perchlorate-reducing bacterium. Water Res. 2008, 42, 2403-2410.

19. Nerenberg, R.; Kawagoshi, Y.; Rittmann, B.E. Kinetics of a hydrogen-oxidizing, perchlorate-reducing bacterium. Water Res. 2006, 40, 3290-3296.

20. Melnyk, R.A.; Clarck, I.C.; Liao, A.; Coates, J.D. Transposon and deletion mutagenesis of genes involved in perchlorate reduction in Azospira suillum PS. MBio 2014, 5, e00769-13. [CrossRef]

21. Bardiya, N.; Bae, J.H. Dissimilatory perchlorate reduction: A review. Microbiol. Res. 2011, 166, 237-254. [CrossRef]

22. Logan, B.E. Assessing the outlook for perchlorate remediation. Environ. Sci. Technol. 2001, 35, 482A-487A. [CrossRef] [PubMed]

23. Xu, J.; Song, Y.; Min, B.; Steinberg, L.; Logan, B.E. Microbial degradation of perchlorate: Principles and applications. Environ. Eng. Sci. 2003, 20, 405-422. [CrossRef]

24. Zhang, H.; Bruns, M.A.; Logan, B.E. Perchlorate reduction by a novel chemolithoautotrophic hydrogen-oxidizing bacterium. Environ. Microbiol. 2002, 4, 570-576. [CrossRef]

25. Martínez-Espinosa, R.M.; Richardson, D.J.; Bonete, M.J. Characterisation of chlorate reduction in the haloarchaeon Haloferax mediterranei. Biochim. Biophys. Acta 2015, 1850, 587-594.

26. Rikken, G.B.; Kroon, A.G.M.; van Ginkel, C.G. Transformation of (per)chlorate into chloride by a newly isolated bacterium: Reduction and dismutation. Appl. Microbiol. Biotechnol. 1996, 45, 420-426. [CrossRef]

27. Coates, J.D.; Achenbach, L.A. Microbial perchlorate reduction: Rocket fuelled metabolism. Nat. Rev. Microbiol. 2004, 2, 569-580. [CrossRef]

28. van Ginkel, C.G.; Rikken, G.B.; Kroon, A.G.M.; Kengen, S.W.M. Purification and characterization of chlorite dismutase: A novel oxygen-generating enzyme. Arch. Microbiol. 1996, 166, 321-326. [CrossRef]

29. Lu, Y.; Chen, J.; Wang, R.; Xu, P.; Zhang, X.; Gao, B.; Guo, C.; Yang, C. Bio-inspired Cu-alginate to smartly enhance safety performance and the thermal decomposition of ammonium perchlorate. Appl. Surf. Sci. 2019, 470, 269-275. [CrossRef]

30. Wolterink, A.F.W.M.; Schiltz, E.; Hagedoorn, P.L.; Hagen, W.R.; Dengen, S.W.M.; Stams, A.J.M. Characterization of the chlorate reductase from Pseudomonas chloritidismutans. J. Bacteriol. 2003, 185, 3210-3213. [CrossRef]

31. Xie, T.; Yang, Q.; Winker, M.K.H.; Wang, D.; Zhong, Y.; An, H.; Che, N.F.; Yao, F.; Wang, X.; Wu, J.; et al. Perchlorate bioreduction linked to methane oxidation in a membrane biofilm reactor: Performance and microbial community structure. J. Hazar. Mat. 2018, 357, 244-252. [CrossRef]

32. Coates, J.D.; Jackson, A. Situ Bioremediation of Perchlorate in Groundwater; Springer: Norwell, MA, USA, 2008.

33. Xu, J.L.; Trimble, J.J.; Steinberg, L.; Logan, B.E. Chlorate and nitrate reduction pathways are separately induced in the perchlorate-respiring bacterium Dechlorosoma sp. KJ and the chlorate-respiring bacterium Pseudomonas sp. PDA. Water Res. 2004, 38, 673-680. [PubMed]

34. Chaudhuri, S.K.; O'Conor, S.M.; Gustavson, R.T.; Achenbach, L.A.; Coates, J.D. Environmental factors that control microbial perchlorate reduction. Appl. Environ. Microbiol. 2002, 68, 4425-4430. [CrossRef] [PubMed]

35. Wallace, W.; Ward, T.; Breen, A.; Attaway, H. Identification of an anaerobic bacterium which reduces perchlorate and chlorate as Wolinella succinogenes. J. Ind. Microbiol. Biotechnol. 1996, 16, 68-72. 
36. Waller, A.S.; Cox, E.E.; Edwards, E.A. Perchlorate-reducing microorganisms isolated from contaminated sites. Environ. Microbiol. 2004, 5, 517-527. [CrossRef] [PubMed]

37. Sun, Y.; Gustavson, R.L.; Ali, N.; Weber, K.A.; Westphal, L.L.; Coates, J.D. Behavioral response of dissimilatory perchlorate-reducing bacteria to different electron acceptors. Appl. Microbiol. Biotechnol. 2009, 84, 955-963. [CrossRef] [PubMed]

38. Carlström, C.I.; Loutey, D.; Bauer, S.; Clark, I.C.; Rohde, R.A.; Iavarone, A.T.; Lucas, L.; Coates, J.D. (Per)chlorate-reducing bacteria can utilize aerobic and anaerobic pathways of aromatic degradation with (per)chlorate as an electron acceptor. Mbio 2015, 6, e02287-14. [CrossRef]

39. Wang, O.; Melnyk, R.A.; Mehta-Kolte, M.G.; Youngblut, M.D.; Carlson, H.K.; Coates, J.D. Functional redundancy in perchlorate and nitrate electron transport chains and rewiring respiratory pathways to alter terminal electron acceptor preference. Front. Microbiol. 2018, 9, 376. [CrossRef]

40. Giblin, T.; Frankenberger, W.T., Jr. Perchlorate and nitrate reductase activity in the perchlorate-respiring bacterium Perc1ac. Microbiol. Res. 2001, 156, 311-315. [CrossRef]

41. Miralles-Robledillo, J.M.; Torregrosa-Crespo, J.; Martínez-Espinosa, R.M.; Pire, C. DMSO Reductase Family: Phylogenetics and Applications of Extremophiles. Int. J. Mol. Sci. 2019, 20, 3349. [CrossRef]

42. Vigliotta, G.; Motta, O.; Guarino, F.; Iannece, P.; Proto, A. Assessment of perchlorate-reducing bacteria in a highly polluted river. Int. J. Hyg. Environ. Health 2010, 213, 437-443. [CrossRef]

43. Rossi, F.; Motta, O.; Matrella, S.; Proto, A.; Vigliotta, G. Nitrate Removal from Wastewater through Biological Denitrification with OGA 24 in a Batch Reactor. Water 2014, 7, 51-62. [CrossRef]

44. Motta, O.; Capunzo, M.; De Caro, F.; Brunetti, L.; Santoro, E.; Farina, A.; Proto, A. New approach for evaluating the public health risk of living near a polluted river. J. Prev. Med. Hyg. 2008, 49, 79-88. [PubMed]

45. Xu, J.; Logan, B.E. Measurement of chlorite dismutase activities in perchlorate respiring bacteria. J. Microbiol. Methods 2003, 54, 239-247. [CrossRef]

46. Iannece, P.; Motta, O.; Tedesco, R.; Carotenuto, M.; Proto, A. Determination of Perchlorate in Bottled Water from Italy. Water 2013, 5, 767-779. [CrossRef]

47. Vigliotta, G.; Tredici, S.M.; Damiano, F.; Montinaro, M.R.; Pulimeno, R.; Di Summa, R.; Massardo, D.R.; Gnoni, G.V.; Alifano, P. Natural merodiploidy involving duplicated rpoB alleles affects secondary metabolism in a producer actinomycete. Mol. Microbiol. 2004, 55, 396-412. [CrossRef] [PubMed]

48. Bruce, R.A.; Achenbach, L.A.; Coates, J.D. Reduction of (per)chlorate by a novel organism isolated from paper mill waste. Environ. Microbiol. 1999, 1, 319-329. [CrossRef] [PubMed]

49. 49 Tamura, K.; Stecher, G.; Peterson, D.; Filipski, A.; Kumar, S. MEGA6: Molecular Evolutionary Genetics Analysis Version 6.0. Mol. Biol. Evol. 2013, 30, 2725-2729. [CrossRef]

50. Unden, G.; Becker, S.; Bongaerts, J.; Schirawski, J.; Six, S. Oxygen regulated gene expression in facultatively anaerobic bacteria. Antonie Leeuwenhoek 1994, 66, 3-22. [CrossRef]

51. Reinhold-Hurek, B.; Hurek, T. Reassessment of the taxonomic structure of the diazotrophic genus Azoarcus sensu lato and description of three new genera and new species, Azovibrio restrictus gen. nov., sp. nov., Azospira oryzae gen. nov., sp. nov. and Azonexus fungiphilus gen. nov., sp. nov. Int. J. Syst. Evol. Microbiol. 2000, 50, 649-659. [CrossRef]

52. Bae, H.-S.; Rash, B.A.; Rainey, F.A.; Nobre, M.F.; Tiago, I.; Da Costa, M.S.; Moe, W.M. Description of Azospira restricta sp. nov., a nitrogen-fixing bacterium isolated from groundwater. Int. J. Syst. Evol. Microbiol. 2007, 57, 1521-1526. [CrossRef]

53. Stackebrandt, E.; Ebers, J. Taxonomic parameters revisited: Tarnished gold standards. Microbiol. Today 2006, 33, 152-155.

54. Coates, J.D.; Michaelidou, U.; Bruce, R.A.; O'Connor, S.M.; Crespi, J.N.; Achenbach, L.A. The ubiquity and diversity of dissimilatory perchlorate reducing bacteria. Appl. Environ. Microbiol. 1999, 65, 5234-5241. [CrossRef] [PubMed]

55. O'Connor, S.M.; Coates, J.D. Universal Immunoprobe for (Per)Chlorate-Reducing Bacteria. Appl. Environ. Microbiol. 2002, 68, 3108-3113. [CrossRef] [PubMed]

56. Shete, A.; Mukhopadhyaya, P.N.; Acharya, A.; Aich, B.A.; Joshi, S.; Ghole, V.S. Aerobic reduction of perchlorate by bacteria isolated in Kerala, South India. J. Appl. Genet. 2008, 49, 425-431. [CrossRef]

57. Coates, J.D.; Michaelidou, U.; O'Connor, S.M.; Bruce, R.A.; Achenbach, L.A. The Diverse Microbiology of (Per)Chlorate Reduction. In Perchlorate in the Environment; Springer Science and Business Media LLC: Berlin, Germany, 2000; pp. 257-270. 
58. Attaway, H.; Smith, M. Reduction of perchlorate by an anaerobic enrichment culture. J. Ind. Microbiol. Biotechnol. 1993, 12, 408-412. [CrossRef]

59. Herman, D.C.; Frankenberger, W.T. Bacterial Reduction of Perchlorate and Nitrate in Water. J. Environ. Qual. 1999, 28, 1018-1024. [CrossRef]

60. Bardiya, N.; Bae, J.-H. Isolation and characterization of Dechlorospirillum anomalous strain JB116 from a sewage treatment plant. Microbiol. Res. 2008, 163, 182-191. [CrossRef]

61. Denis, K.S.; Dias, F.M.; Rowe, J.J. Oxygen regulation of nitrate transport by diversion of electron flow in Escherichia coli. J. Biol. Chem. 1990, 265, 18095-18097.

62. Bell, L.C.; Richardson, D.J.; Ferguson, S.J. Periplasmic and membrane-bound respiratory nitrate reductases in Thiosphaera pantotropha. FEBS Lett. 1990, 265, 85-87. [CrossRef]

63. Berks, B.C.; Ferguson, S.J.; Moir, J.W.B.; Richardson, D.J. Enzymes and associated electron transport systems that catalyse the respiratory reduction of nitrogen oxides and oxyanions. Biochim. Biophys. Acta (BBA) Bioenerg. 1995, 1232, 97-173. [CrossRef]

64. Bedzyk, L.; Wang, T.; Ye, R.W. The Periplasmic Nitrate Reductase inPseudomonas sp. Strain G-179 Catalyzes the First Step of Denitrification. J. Bacteriol. 1999, 181, 2802-2806. [CrossRef] [PubMed]

65. Dobao, M.M.; Martínez-Luque, M.; Moreno-Vivián, C.; Castillo, F. Effect of carbon and nitrogen metabolism on nitrate reductase activity of Rhodobacter capsulatus E1F1. Can. J. Microbiol. 1994, 40, 645-650. [CrossRef]

66. Reyes, F.; Roldán, M.D.; Klipp, W.; Castillo, F.; Moreno-Vivián, C.; Reyes-Ramirez, F. Isolation of periplasmic nitrate reductase genes from Rhodobacter sphaeroides DSM 158: Structural and functional differences among prokaryotic nitrate reductases. Mol. Microbiol. 1996, 19, 1307-1318. [CrossRef] [PubMed]

67. A Siddiqui, R.; Warnecke-Eberz, U.; Hengsberger, A.; Schneider, B.; Kostka, S.; Friedrich, B. Structure and function of a periplasmic nitrate reductase in Alcaligenes eutrophus H16. J. Bacteriol. 1993, 175, 5867-5876. [CrossRef]

68. Mehboob, F.; Junca, H.; Schraa, G.; Stams, A.J.M. Growth of Pseudomonas chloritidismutans AW-1T on n-alkanes with chlorate as an electron acceptor. Appl. Microbiol. Biotechnol. 83, 739-747. [CrossRef]

69. Weelink, S.A.B.; Tan, N.C.G.; Broeke, H.T.; Kieboom, C.V.D.; Van Doesburg, W.; Langenhoff, A.A.; Gerritse, J.; Junca, H.; Stams, A.J.M. Isolation and Characterization of Alicycliphilus denitrificans Strain BC, Which Grows on Benzene with Chlorate as the Electron Acceptor. Appl. Environ. Microbiol. 2008, 74, 6672-6681. [CrossRef]

70. Bender, K.S.; O'Connor, S.M.; Chakraborty, R.; Coates, J.D.; Achenbach, L.A. Sequencing and Transcriptional Analysis of the Chlorite Dismutase Gene of Dechloromonas agitata and Its Use as a Metabolic Probe. Appl. Environ. Microbiol. 2002, 68, 4820-4826. [CrossRef]

71. Michaelidou, U.; Achenbach, L.A.; Coates, J.D. Isolation and Characterization of Two Novel (Per)Chlorate-Reducing Bacteria from Swine Waste Lagoons. In Perchlorate in the Environment; Springer Science and Business Media LLC: Berlin, Germany, 2000; pp. 271-283.

72. Bender, K.S.; Rice, M.R.; Fugate, W.H.; Coates, J.D.; Achenbach, L.A. Metabolic Primers for Detection of (Per)chlorate-Reducing Bacteria in the Environment and Phylogenetic Analysis of cld Gene Sequences. Appl. Environ. Microbiol. 2004, 70, 5651-5658. [CrossRef]

73. Ebihara, A.; Okamoto, A.; Kousumi, Y.; Yamamoto, H.; Masui, R.; Ueyama, N.; Yokoyama, S.; Kuramitsu, S. Structure-based functional identification of a novel heme-binding protein from Thermus thermophilus HB8. J. Struct. Funct. Genom. 2005, 6, 21-32. [CrossRef]

74. Melnyk, R.A.; Youngblut, M.D.; Clark, I.C.; Carlson, H.K.; Wetmore, K.M.; Price, M.N.; Iavarone, A.T.; Deutschbauer, A.M.; Arkin, A.P.; Coates, J.D. Novel Mechanism for Scavenging of Hypochlorite Involving a Periplasmic Methionine-Rich Peptide and Methionine Sulfoxide Reductase. mBio 2015, 6, e00233-15. [CrossRef]

(C) 2020 by the authors. Licensee MDPI, Basel, Switzerland. This article is an open access article distributed under the terms and conditions of the Creative Commons Attribution (CC BY) license (http://creativecommons.org/licenses/by/4.0/). 